\title{
Art in Special Collections: Latino and African American Fine Art and Photography Collections in Academic Institutions
}

\author{
Rebecca Hankins and Miguel Juárez
}

Often university libraries or archive/special collections house large fine art and photographic collections by African American and Latino artists. These collections are frequently hidden due to inadequate funding to promote them, minimal exhibit space, insufficient staffing with requisite exhibition and curatorial expertise, and/or diminished cataloging or digital priority. This article seeks to address the concerns and issues that affect this lack of exposure within academic special collections in both large and small institutions. The intent is to highlight successful strategies that can be used by other repositories seeking to diversify their art and photography holdings.

\section{Introduction}

Academic libraries and archive/special collections on university campuses often house large art collections of paintings, sculptures, prints, and photographs. Some of these collections include African American and Latino fine artists and photographers, but these materials are hidden gems within their broader, extensive holdings. For example, the Texas A\&M University's Cushing Library and Special Collections has a substantial photographic portfolio of the Afro-Peruvian and Afro-Brazilian communities by Peruvian photographer Lorry Salcedo-Mitrano, photographer/journalist Manuela Gomez's photographs of the Juarez, Mexico, community, and a collection of fine art and prints from African American printmaker Charles Criner. The University of Texas at El Paso has a collection of photographs from the late Mexican photographer Manuel Carrillo, as well as prints from José Cisneros. Texas Southern University owns the works of renowned African American artist and educator John Biggers, and the California Ethnic and Multicultural Archives (CEMA) in the Department of Special Collections at the Donald C. Davidson Library at University of California Santa Barbara maintains the extensive online Digital Chicano Art collection (http://www.library.ucsb.edu/speccoll/collections/cema/ digitalChicanoArt.html).

Many of these art collections and other works by well known African American and Latino artists are often hidden from the larger community due to lack of funding, inadequate descriptive tagging or cataloging, small or no exhibition space or staffing with no exhibition expertise, diminished digital priority that results in a lack of Internet/Web presence, and serious copyright and other legal concerns. These factors also contribute to the lack of community knowledge of these collections and prevent access to the materials. The authors sought to address some of these issues through a survey of twenty institutions that represented a cross section of university special collections. Large and small institutions, designated Hispanic Serving Institutions (HSI) and Historically Black Colleges and Universities (HBCUs), were chosen. Due to an inadequate response rate, however, the authors felt the data was inconclusive. The original survey was not included as part of the summary of findings, and the authors developed a larger survey for future research. This article will instead present some best practices and suggestions for outreach that include a discussion of cultural competence as a guiding principal for diversifying special collections, barriers to collecting that speak to how value is determined, strategies for overcoming community donor resistance, and alternatives for providing researchers and the community of learners access to these collections.

\section{Literature Review}

The literature review on ethnic collections in archival institutions returned very few articles on African American and Latino artistic projects that discuss how to document these resources.

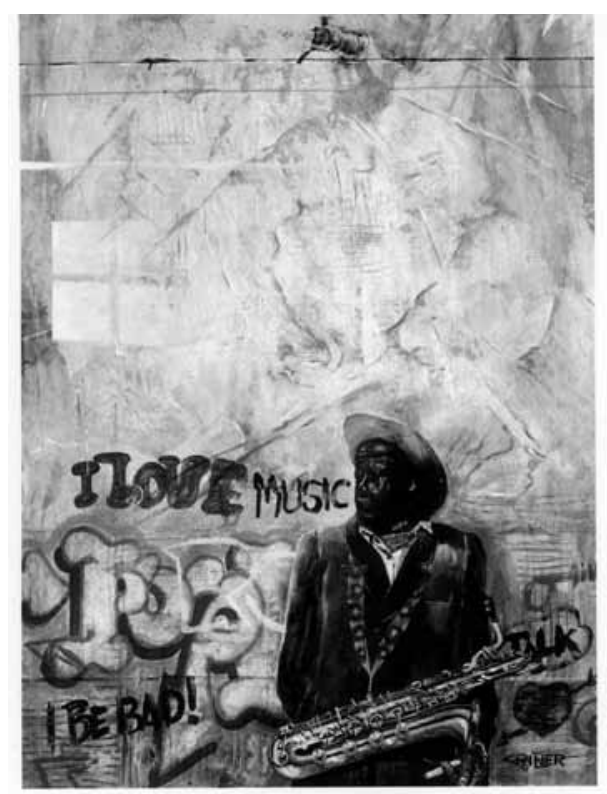

Figure 1: Charles Criner. Blues Man. Painting from the Charles Criner Art Collection and Papers, 1960-2009. Reproduced with permission of the artist and through the courtesy of Cushing Memorial Library and Archives, Texas AEM University Libraries. 


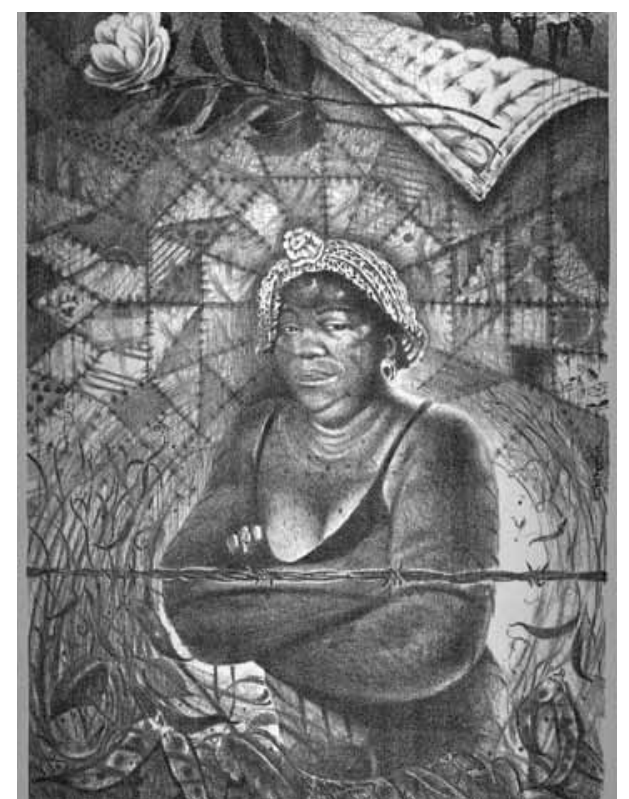

Figure 2: Charles Criner. Juneteenth. Painting from the Charles Criner Art Collection and Papers, 1960-2009. Reproduced with permission of the artist and through the courtesy of Cushing Memorial Library and Archives, Texas A\&M University Libraries.

Two articles in particular capture the importance of documenting and collecting Latino art: the University of California Los Angeles (UCLA) Chicano Studies Research Center's Latino Policy \& Issues Brief written by Rita Gonzalez entitled, "Archiving the Latino Arts Before It is Too Late (2003)"1 and Taina B. Caragol's "Archives of Reality: Contemporary Efforts to Document Latino Art (2005)." ${ }^{2}$

The Gonzalez article provides a historical account of UCLA's attempts to document the history of Latino artistic production. She describes how these resources were then made available through the digital project Online Archive of California. ${ }^{3}$ The Chicano Studies Research Center (CSRC) at UCLA is also developing an image database of collections working in partnership with the UCLA Digital Library Program. ${ }^{4}$ Another significant effort described by Gonzalez is Calisphere, ${ }^{5}$ the University of California's free public gateway to a world of primary sources. Content for Calisphere has been selected from the libraries and museums of the UC campuses, and from a variety of cultural heritage organizations across California. Gonzalez also offers recommendations for continuing these efforts that include coordinating partnerships with the Latino arts community by the CSRC, surveying existing collections, increasing community awareness, and collecting some of these materials.

Taina Caragol's article follows up on some themes in the Gonzalez article that are specifically related to the need for more collaborative partnerships to document these collections. She discusses new opportunities to ensure that these histories are not lost; they include a multi-institutional project that partners the Chicano Studies Research Center at UCLA, The Metropolitan New York Library Council's Survey of Archives of Latino Art, The Smithsonian Institution's Archives of American Art, and the International Center for the Arts of the Americas at the Museum of Fine Arts in Houston. Caragol notes that, "Not only are the documentation projects giving a boost to efforts to conserve and make Latino archives accessible; they also are creating awareness among Latino art communities of the interdependence between safeguarding their archives and writing their histories." 6 She further notes that documenting these works will help "recognize the role Latinos played in developing the nation's contemporary culture and in creating community-based art. These contributions have often gone unacknowledged owing to a lack of historical evidence." ${ }^{\prime 7}$

The only example of a national comprehensive survey of African American collections is the Cooperative HBCU Archival Survey Project (CHASP), an NEH-funded project from the 1990s designed to examine and catalog the collections of ninety-nine Historically Black Colleges and Universities (HBCUs). The collections surveyed were mostly manuscript or photographic materials. As noted in the Library of Congress online newsletter, "These materials are generally unknown to researchers because they are not listed in existing reference tools and databases." ${ }^{8}$ African American art collections in universities were not the focus of the CHASP project, nor have they been systematically inventoried or documented except on an individual basis within a collecting repository. The documentation of these collections on not only HBCU campuses, but also on predominantly white campuses, is a task that needs to be pursued. The Amistad Research Center ${ }^{9}$ at Tulane University in New Orleans, for example, houses the Aaron Douglas art collection, widely considered one of the Deep South's largest and most celebrated art collections with works by many African American masters such as Aaron Douglas, Hale Woodruff, William H. Johnson, Jacob Lawrence, Palmer Hayden, Claude Clark, Ellis Wilson, William Artis, Richmond Barthe, Elizabeth Catlett, and Selma Burke. The Paul R. Jones Collection of African American Art is housed at the University of Delaware, and the David C. Driskell Center that features African American art works is at the University of Maryland. The CHASP project and the survey of archives of Latino art collections have met with great success in identifying,

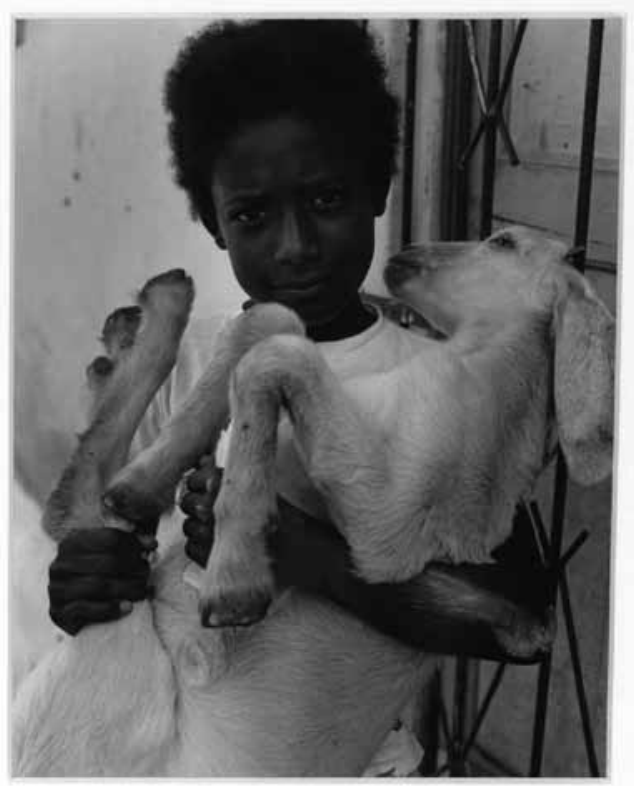

Figure 3: Lorry Salcedo Mitrani. Pet Goat, Bahia, Brazil. From the artist's collection of photographs entitled "Africa's Legacy: Photographs in Brazil and Peru." Reproduced with permission of the artist and through the courtesy of Cushing Memorial Library and Archives, Texas AEM University Libraries. 
cataloging, and providing access to African American manuscript and Latino artistic production.

There are also a few articles that describe the growth of ethnic art collections developed in response to the lack of diversity within cultural institutions. A number of these articles reference the work done from a global perspective that has recognized the need to collect and preserve the artistic output of diverse populations. The Living Archive that preserves the artistic production of African and Asian artists in London is one such endeavor. ${ }^{10}$ Another project discusses the National Gallery of Australia in Canberra's acquisition of the Australian Print Workshop Archive that includes collections of Indigenous Australian and Torres Strait Islander prints, and prints by artists from Aotearoa New Zealand, Papua New Guinea, the Pacific Islands, and South East Asia. ${ }^{11}$ Other articles examine individual museum collections outside of the academic sphere. An excellent monograph, Challenging Racism in the Arts, covers the problems related to the lack of adequate representation within collections in the nation's cultural institutions by using case studies. The book discusses issues related to "the struggle over cultural representation in both popular and high culture."12

These articles, projects, and works acknowledge the strong need to ensure that cultural institutions reflect the diversity of all of America's citizens. This means not only collecting these works and materials, but also creating a variety of avenues for access within the archival, museum, and historical centers throughout the educational and artistic communities. Providing access for the public to view and use these materials acknowledges the contributions of all citizens and is an impetus for diversifying art collections through donations and purchases. This article will add to and update some of the recommendations suggested in Gonzalez's call to action.

\section{Diversity and Cultural Competence for Special Collections}

Cultural competence is defined as a "set of congruent behaviors, attitudes, and policies that come together in a system, agency, or among professionals and enables that system, agency, or those professionals to work effectively in cross-cultural situations."13 Operationally defined, cultural competence is the integration and transformation of knowledge about individuals and groups of people into specific standards, policies, practices, and attitudes used in appropriate cultural settings to increase the quality of services, thereby producing better outcomes. ${ }^{14}$ How can archives and archivists within the field exhibit cultural competence that represents a sincere effort to diversify collections? One simple way of representing cultural competence in special collections is to develop mission statements and collecting policies that include Latino and African American art. These written documents are important in establishing the parameters of collecting and provide a public acknowledgement that diversity is a valued aspect of the institution. The importance of documenting all of America's constituent groups, especially those underserved and underrepresented in collections, requires cultural competence that has the weight of documentation which is accessible and publicized.

A question posed to the Archives and Archivists Listserv a few years ago asked, "How do you get underserved populations to use your archival facility?" There is the implied supposition that there are materials already in one's archives that will

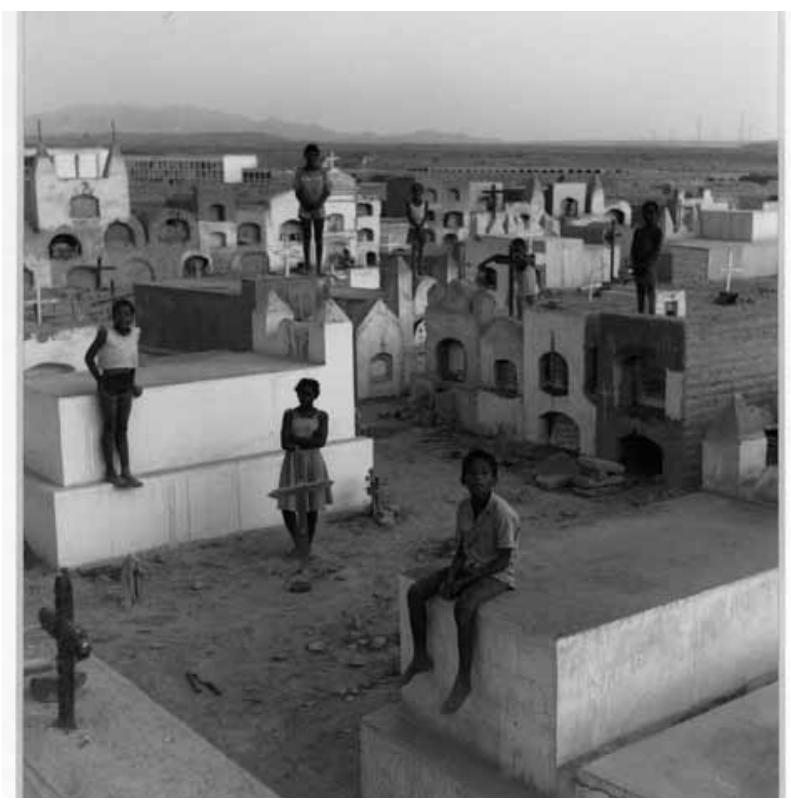

Figure 4: Lorry Salcedo Mitrani. Playing at the Cemetery, Peru. From the artist's collection of photographs entitled Africa's Legacy: Photographs in Brazil and Peru. Reproduced with permission of the artist and through the courtesy of Cushing Memorial Library and Archives, Texas AEM University Libraries.

both bring these populations in as users and encourage them to become donors. How does one develop a policy for an institution that will reflect a reasonable and sincere effort to collect the treasures within these communities in the area? What is the best way to encourage people to donate when the institution has not actively collected in those areas? This concerns especially art collections that represent not just creative expression but convey historical and cultural memory not captured in books or papers. The need to display a sincerity that is expressed through cultural competence provides the foundation for establishing a trust relationship that is paramount to building representative collections.

Building representative collections should go hand-in-hand with ensuring that institutions have diverse professionals that represent the rapidly changing demographics within society. The need to diversify the workforce has been the impetus for both the American Library Association and the Society of American Archivists to develop outreach and funding programs to bring in diverse individuals to serve these populations. Diversifying the library and archival professions offers opportunities to operationally implement cultural competence. Studies have shown that having a multicultural and diverse staff encourages use of library resources and provides a welcoming environment for students of color who often feel a sense of isolation and loneliness on many of the predominantly white campuses that house large Latino and African American resources. Seeing someone who "looks like you" can help a reluctant student of color use the resources of an archives or library.

Developing outreach programs that are responsive to diverse populations is essential to the longevity of institutions. It is important to understand that the reluctance and suspicion that many institutions encounter should be expected when outreach has not been done in the past. The need to be consistent, steadfast, and sensitive should be the mantra of academia and the archival repositories. Trust will take some time to establish, but 
as the higher education landscape moves closer toward reflecting society's demographics, students and alumni will see the value in ensuring that their cultural and artistic legacy is captured for succeeding generations.

\section{Overcoming Barriers to Collecting and Strategies for Providing Access}

During the late 1990s and early twenty-first century, the warning about the digital divide - the lack of access by part of the population to information technologies and computers-was constantly heard. At the time scholars were alarmed. In 2000, Reid Goldsborough stated "The digital divide... is now one of America's leading economic and civil rights issues according to the U.S. Department of Commerce's most recent report on the subject." 15 Much of the remedy for that situation, although not yet a complete solution, was effected by the increase in the number of computers in public libraries and public institutions such as community centers. The current digital divide is now less about access to computers and technology than about providing content both electronically and digitally at high speeds. Norris Dickard and Diana Schneider stated that "an inability to access the enhanced content available via broadband is creating a second-generation divide."16 In 2007 the U.S. Congress appropriated $\$ 4.7$ billion to establish the Broadband Technology Opportunities Program (BTOP) that provides awards to eligible entities to develop and expand broadband services to unserved and underserved areas and improve access to broadband by public safety agencies. ${ }^{17}$ This effort is similar to the push of federally funded programs such as the E-Rate and the Technology Opportunities Program that encouraged collaborative digital technology programs between the public and private sector. The BTOP continues to provide funding under President Obama's American Recovery Reinvestment Act, giving rural and underserved communities access to the Internet and exposing them to the wealth of resources and collections within academic institutions. Is it really a leap from expanding broadband access to the collecting of diverse collections? How do we get underserved populations through our doors and using our collections? By making sure we are collecting materials on these populations and providing access through cataloging and digitization projects. The physical door is not the only portal for viewing an institution's holdings. Providing collections via digital projects is a virtual door that goes hand in hand with providing multiple levels of access. These collections have content that encourages, celebrates, and acknowledges the contributions of all groups within society and can be the impetus that pushes the underrepresented communities to donate to repositories and seek broadband access to expand their knowledge of other resources.

Anyone working in the collection development side of the library/archive profession will confirm that building culturally diverse collections requires the convergence of a number of characteristics, including aggressiveness, persistence, creativity, thick skin, and ultimately luck-being at the right place at the right time. The archivist should strive to have collections that represent the entire populations within an institution, especially land grant campuses whose mission to educate is intended for all citizens within the state. Working to develop culturally diverse collections is important not just for current citizens, but also for future generations. The changing demographics are one major reason to diversify holdings; in Texas alone, by 2040, 67.8 percent of the children under the age of seventeen will be Latino. These issues are tied in to cultural competence and cultural valuewho determines it and what value is placed on it in contrast to other cultural materials.

Value is something we give to things. What is more valuable, the 1855 edition of Walt Whitman's Leaves of Grass or Luis Valdez's Zoot Suit script with handwritten notes in the margins? Both have value - the difference is that one needs specialists who recognize the intrinsic value of each. In academic libraries, the value further translates into personnel needed to process these materials and make them accessible to researchers and students. One of the most important recommendations of the Gonzalez article is the need to "increase the acquisition of and access to material through the hiring of bilingual area specialists with archival expertise..."18

Working with the premise that the libraries, archives, and cultural institutions hold millions of items that have never been adequately described, the Council on Library and Information Resources, an independent, nonprofit organization, sponsors Hidden Collection Awards that seek to promote collections that would otherwise be unknown if there were no resources to make them "visible" by processing or cataloging them. Other institutions that can assist in developing access projects include the Institute of Museum and Library Services with its grants for digitization and preservation/conservation, the National Endowment for the Humanities and the National Endowment for the Arts, the Andrew J. Mellon Foundation that provides

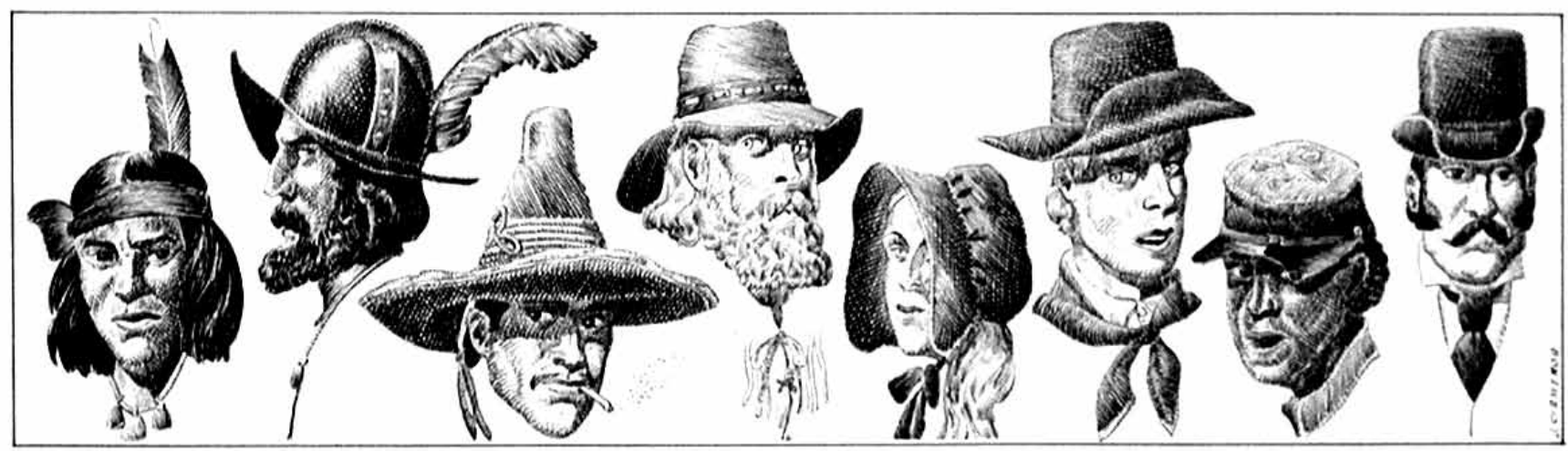

Figure 5: José Cisneros. Faces. Drawing. Texas Western Press Records, MS366. Image Courtesy of the C.L. Sonnichsen Special Collections Department, University of Texas at El Paso Library. 
funding for digital projects for underserved communities, the Getty Foundation, the National Historical Publications and Records Commission, many state agencies and programs, and local arts councils.

\section{Future Research}

The authors initially surveyed twelve special collections at schools that are considered to be peer institutions to Texas A\&M University using the Carnegie Academic Classification system. Eight additional Texas institutions that are designated Hispanicand African American-serving institutions were then added. The response rate was disappointing, and it amplifies the issues discussed in this article regarding the hidden aspect of many of these resources and possibly issues that relate to the hierarchy of importance. Future research should expand the scope to include institutions that can address some of the geographic- and demographic-influenced issues that came out of the original survey. Does the majority-minority status affect whether a repository has these materials? What are the differences regionally and are there more African American and Latino art collections in Texas or California, both majority-minority states, than in Kansas or Iowa? What does the lack of these collections in the northern states mean in terms of building diverse resources for all constituent populations wherever they may be? Does having a vibrant African American or Hispanic Studies Department within an institution assist or translate into an increase in related art and photographic collections? Can these types of conclusions be drawn based on resources, or are there other factors, such as funding, personnel, or space issues? The answers to these questions will provide academic special collections with methods and processes that can be instrumental in the quest to diversify their holdings.

\section{Conclusions}

This article makes clear that there are a number of issues that continue to contribute to a lack of African American and Latino fine art and photographic collections in major academic institutions, although there are now more attempts to build these resources. Those institutions that do include African American and Latino art collections have significant holdings, but often lack the personal papers of the individual artists. These institutions should encourage their donors to include papers to build up the research aspects of their collections. As the Smithsonian's Archives of American Art has proven, having the papers of the artists encourages others to research their lives and output, in turn producing scholarly articles and books that expand knowledge of and access to these works. Scholarly articles and books also will place these artists within the canon of scholarship. Having personal papers invites others to build on their works, interpreting and re-interpreting them for future scholarship and learning.

Special collections staff should ensure that their art and photographic collections are cataloged in national or local databases. Virtual access to holdings via the Internet is essential in these times where many people use a search engine such as Google or Yahoo to discover information. It is also important to have in place diverse personnel charged with outreach to the African American or Latino communities in academia and the larger community. Institutions should be aware of the impact

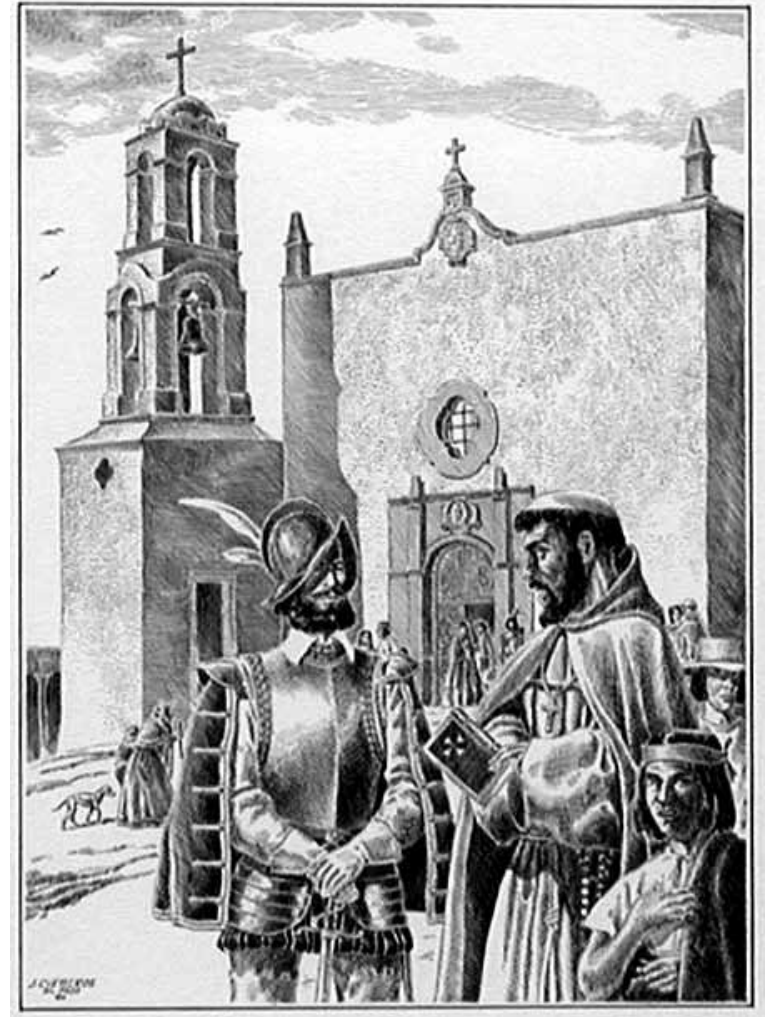

Figure 6: José Cisneros. Nuestra Señora. Drawing. Texas Western Press Records, MS366. Image Courtesy of the C.L. Sonnichsen Special Collections Department, University of Texas at El Paso Library.

of the demographics within their locale and any shifts that will inevitably impact their future donors or future collecting priorities. In states such as Georgia and Maryland that are predicted to achieve majority-minority status within the next few years, special collections staff should now be discussing and making decisions about providing materials to underrepresented populations that could impact their funding and continued growth. In 2007 and 2008, CNN reported that there were majority-minority counties in Kansas, Florida, and Mississippi along with additional counties in California and Texas, states that had already achieved majority-minority status. ${ }^{19}$ Archives/special collections have an important role to play in providing an environment that is welcoming and that acknowledges the value and worth of African American and Latino fine art and photography.

Dr. Gregory Cuellar, in an e-mail exchange, noted that "Archives do not simply exist as spaces from which historical truth can be discerned, they are part of the very constitution of knowledge that determines how truth is known." ${ }^{20}$ Society of American Archivists President Mark Greene also stated, "Archivists are professionals with the power of defining and making accessible the primary sources of history, primary sources that protect rights, educate students, inform the public, and support a primal human desire to understand our past." ${ }^{21}$ These words are a heavy burden and responsibility shared by archivists and special collections librarians who bring recognition of the diversity of our country and society, diversity of our resources and history, diversity of views and viewpoints, a voice to the voiceless. Moreover, archivists have a responsibility that is central to the SAA Archival Values: "We value access because we hold use as our highest value." The American Library 
Association's Core Values reads "All information resources that are provided directly or indirectly by the library, regardless of technology, format, or methods of delivery, should be readily, equally, and equitably accessible to all library users." 22 These are values that must be kept in the forefront and that are the foundation of library and archival work. The charge to collect representational collections is paramount, but ensuring that there is access is no less important.

There are some bright spots and models for institutions that are working towards acquiring and providing access to African American and Latino collections that were mentioned earlier in the article. The Chicano Studies Research Center partnering with national and educational institutions to document Latino art and CEMA's work in conjunction with Calisphere in the creation of their Digital Chicano Art Project are models that need duplication throughout the United States. The Council on Library and Information Resources and other funding agencies are providing grants for academic institutions to partner with historical and nonprofit organizations to document and discover hidden collections within local communities. These initiatives provide excellent opportunities for outreach to the communities of color, but can also serve as opportunities to build archival holdings.

Texas A\&M University's Cushing Library \& Special Collections represents one of those institutions that can serve as a model for other institutions. They have incorporated many of the positive attributes mentioned in this article, such as providing a mission statement and collecting policy that is inclusive; cataloging their holdings and providing finding guides for their collections; providing exhibits, both physical and online, that showcase their African American and Latino collections, and also loaning them to other organizations and institutions to raise their visibility; and having in place professionals that can respond to the needs of these communities. Texas institutions like Texas A\&M University do serve as models for many of the institutions that will invariably experience the growing pains of a more multicultural society within the next ten to twenty years. Systemically addressing these issues now will not only reinforce the idea that all constituent groups are valued, but it builds a lasting trust that is sorely needed when reaching out to African American and Latino populations. The need to get in front of this issue and actively reach out to these underrepresented populations is not only the smart move to make, but it will strategically prepare these institutions for their new users.

\section{Notes}

1. Rita Gonzalez, "Archiving the Latino Arts Before it is Too Late," Latino Policy E Issues Brief (Los Angeles: UCLA Chicano Studies Research Center, 2003).

2. Taina B. Caragol, "Archives of Reality: Contemporary Efforts to Document Latino Art," American Art 19, no. 3 (Fall 2005): $2-8$.

3. Online Archive of California, http://www.oac.cdlib. org/.

4. UCLA Chicano Studies Research Center, CSRC Archival Projects, http://www.chicano.ucla.edu/library/arch/archiveprojects.asp.

5. Calisphere, University of California, http://www. calisphere.universityofcalifornia.edu/.

6. Caragol, "Archives of Reality," 8.

7. Ibid, 1.
8. "National Union Catalog of Manuscript Collections (NUCMC)," LC Cataloging Newsline 10, no. 7 (July 2002), http:// www.loc.gov/catdir/lccn/lccn1007.html (accessed August 20, 2009).

9. Amistad Research Center, http://www.amistadresearchcenter.org/arc-art.htm.

10. “AAVAA's 'The Living Archive' Papers," Third Text 54 (Spring 2001): 85-110.

11. Nick Waterlow, "Hosting Place Made: Australian Print Workshop," Artonview 42 (Winter 2005): 48-49.

12. Carol Tator, Frances Henry, and Winston Mattis, Challenging Racism in the Arts: Case Studies of Controversy and Conflict (Toronto: University of Toronto Press, 1998), 214.

13. Terry L. Cross, Towards a Culturally Competent System of Care (Washington, DC: Georgetown University, 1998), http:// cecp.air.org/cultural/Q integrated.htm\#def (accessed April 18, 2008).

14. K. Davis, Exploring the Intersection Between Cultural Competency and Managed Behavioral Health Care Policy: Implications for State and County Mental Health Agencies (Alexandria, VA: National Technical Assistance Center for State Mental Health Planning, 1997).

15. Reid Goldsborough, "Bridging the Digital Divide,"

Black Issues in Higher Education 16, no. 27 (March 2, 2000): 46.

16. Norris Dickard and Diana Schneider, "The Digital

Divide: Where We Are," Edutopia (The George Lucas

Educational Foundation, 2009), http:/ / www.edutopia.org/ digital-divide-where-we-are-today (accessed August 20, 2009).

17. National Telecommunications and Information

Administration, http://www.ntia.doc.gov/otiahome/otiahome.html (accessed October 24, 2009).

18. Gonzalez, "Archiving the Latino Arts Before it is Too Late," 3.

19. Sean Callebs, "Whites Become the Minority in Kansas Town," http://www.cnn.com/2009/LIVING/ wayoflife/05/22/garden.city.kansas.minorities/index.html (accessed August 31, 2009).

20. Gregory Cuellar, e-mail to Rebecca Hankins, August 29, 2007.

21. Mark A. Greene, "The Power of Archives: Archivists' Values and Value in the Postmodern Age," American Archivist 72, no. 1 (Spring/Summer 2009): 34.

22. American Library Association Core Values of Librarianship, http://www.ala.org/ala/aboutala/offices/oif/ statementspols/corevaluesstatement/corevalues.cfm\#access (accessed October 18, 2009).
Rebecca Hankins, Assistant Professor of Library Science, Africana Resources Librarian/Curator, Texas AEM University, College Station, Texas, RHankins@lib-gw.tamu.edu

Miguel Juárez, Assistant Instructor, History Department, University of Texas at El Paso, El Paso, Texas, migueljuarez.soha@gmail.com 